\title{
BASIC PRINCIPLES OF AN ASSESSMENT OF THE MORPHOLOGICAL CONDITION OF THE BIOLOGICAL KIDNEY TISSUES IN THE PRISM OF LASER POLARIMETRY
}

\section{T.M. Boichuk, O.I. Petryshen, H.M. Chernikova, S.B. Yermolenko *}

\begin{abstract}
The polarization properties of the biological tissues of the kidney in health and under the conditions pathology induced by the nephrotoxic action of metal salts were studied on histological sections. The diagnostic criteria were evaluated on the basis of a statistical, correlation and fractal analysis of the architectonic structure of polarized laser images.

Key words: morphology, kidney, laser polarimetry.
\end{abstract}

Bukovinian State Medical University (Chernivtsi)

* Yuriy Fedkovych National University (Chernivtsi)

\author{
О.Я. Ванчуляк
}

\section{ПРИНЦИПИ ДОКАЗОВОЇ МЕДИЦИНИ ДЛЯ ЛОКАЛЬНОГО МАСШТАБНО-СЕЛЕКТИВНОГО КОРЕЛЯЩЙНОГО АНАЛІЗУ РОЗПОДІЛІВ ЕЛІПТИЧНОСТІ ПОЛЯРИЗАЦІЇ ЛАЗЕРНИХ ЦИФРОВИХ МІКРОСКОПІЧНИХ ЗОБРАЖЕНЬ МІОКАРДА ЗА УМОВ ГОСТРОЇ ІШЕМІЇ}

Буковинський державний медичний університет, м. Чернівці

Резюме. У роботі висвітлено показники, що об'єктивно свідчать про пошкодження міокарда людини за умов гострої ішемії. На засадах принципів доказової медицини обгрунтовано доцільність використання вейвлет-аналізу кореляційної структури мап еліптичності поляризації лазерних зображень міокарда для діагнос- тики гострої коронарної недостатності та визначено операційні характеристики сили даного методу.

Ключові слова: поляризаційна мікроскопія, гостра коронарна недостатність міокарда, судово-медична експертиза.
Вступ. Актуальність дослідження в першу чергу пов'язана із необхідністю розширення інформаційної бази (урахування не тільки розподілів азимутів, що характеризують оптичну активність міозину, але й еліптичності поляризації, що характеризує структурованість сіток міозинових фібрил) для масштабно-селективного вейвлет-аналізу.

Мета дослідження. Пошук та встановлення взаємозв'язку між даними вейвлет-аналізу кореляційної структури мап еліптичності поляризації лазерних зображень міокарда при гострій коронарній недостатності (ГКН) та визначення на цій основі інформативності даного методу.

Матеріал і методи. Матеріалом дослідження були нативні зрізи міокарда людини товщиною $30 \pm 5$ мкм, виготовлені за допомогою заморожуючого мікротома: 27 зразків складали зрізи міокарда померлих із хронічною ішемічною хворобою серця (XIXC), 30 зразків - забрані від трупів померлих від ГКН. Після чого зрізи досліджувались із використанням оптичної схеми в традиційному зображенні поляриметра [1]. Використовували пучок ( $\varnothing=10_{4}$ мкм) He-Ne лазера $(\lambda=$ 0.6328 мкм) [3].

Основний інформаційний засіб для аналізу поляризаційних мікроскопічних зображень зрізів (C) О.Я. Ванчуляк, 2013 міокарда ми застосовували вейвлет-аналіз. 3 використанням програмного продукту MATLAB.

Як об'єкт для дослідження ми обрали координатний розподіл еліптичності поляризації в площині мікроскопічного зображення міокарда, який проводився програмою MatLab. Проведено лінійне $k 1, \ldots, k m ; k=1 \div n$ сканування МНАТ - вейвлетом із кроком $b=1 p i x \quad 3$ розмірами вікна $1 \mu m \leq a_{m i n} \leq 70 \mu m$. МНАТ - функцію, це - вейвлет функція, друга похідна Гаусової функції [2]. Для оцінювання координатної впорядкованості розподілу еліптичності поляризації в площині гістологічного зрізу міокарда використовувався метод автокореляції.Для оцінки розподілів власних значень автокореляційних функцій $K(\Delta x)$ на різних масштабах $a$ вейвлет-функції $\psi$ обчислювалася сукупність їх статистичних моментів 1-4-го порядків $M_{j=1 ; 2 ; 3 ; 4}$.

В основу визначення інформативності даного об'єктивного аналізу з позицій доказової медицини покладено чутливість $(\mathrm{Se})$, специфічність $(S p)$, точність $(A c)$, прогностичність від’ємного результату (-VP), Прогностичність позитивного результату $(+V P)$.

Результати дослідження та їх обговорення. У результаті сканування обчислено двовимірну 


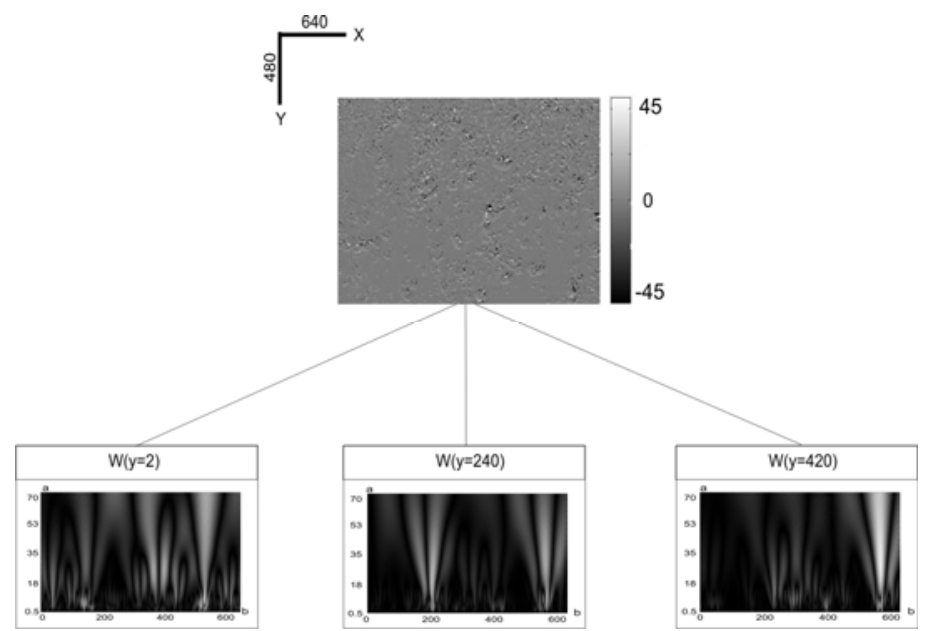

Рис. 1. Розподіли вейвлет-коефіцієнтів поляризаційної мапи еліптичності поляризації лазерного цифрового мікроскопічного зображення міокарда групи 1 для різних рядків CCD - камери: а) - $k=2$; б) - $k=240$; в) - $k=420$

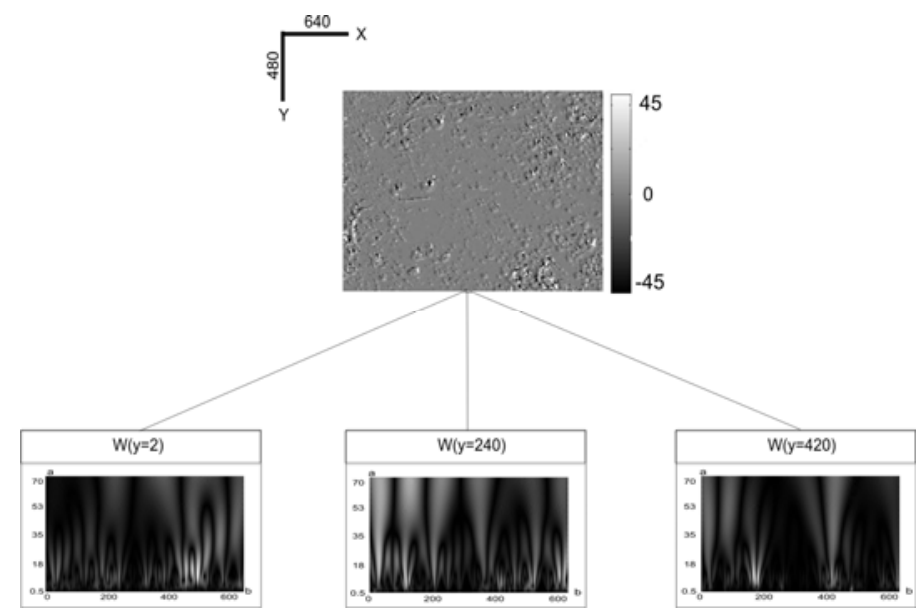

Рис. 2. Розподіли вейвлет-коефіцієнтів поляризаційної мапи еліптичності поляризації лазерного цифрового мікроскопічного зображення шару міокарда групи 2 для різних рядків CCD - камери: a) - $k=2$; б) - $k=240$; в) - $k=420$

$$
a_{\min }=2 \mu m
$$

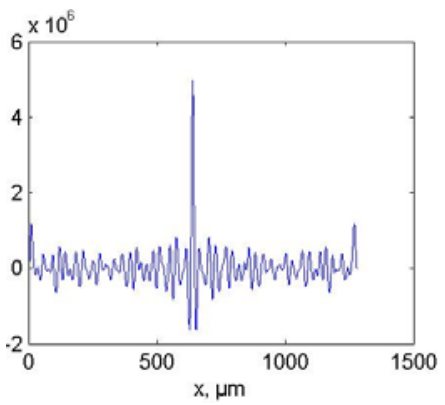

б

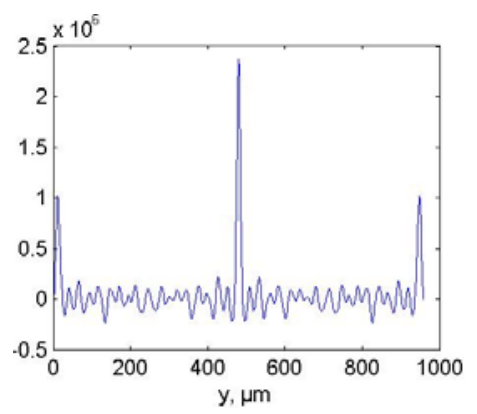

$a_{\min }=10 \mu m$
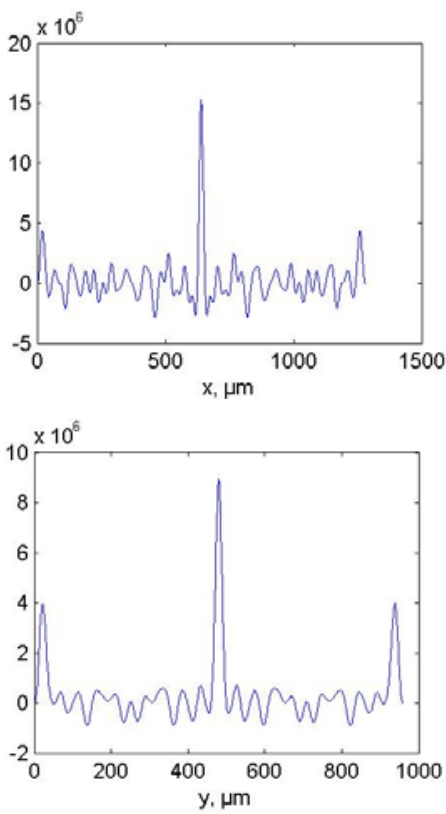

$a_{\min }=30 \mu m$
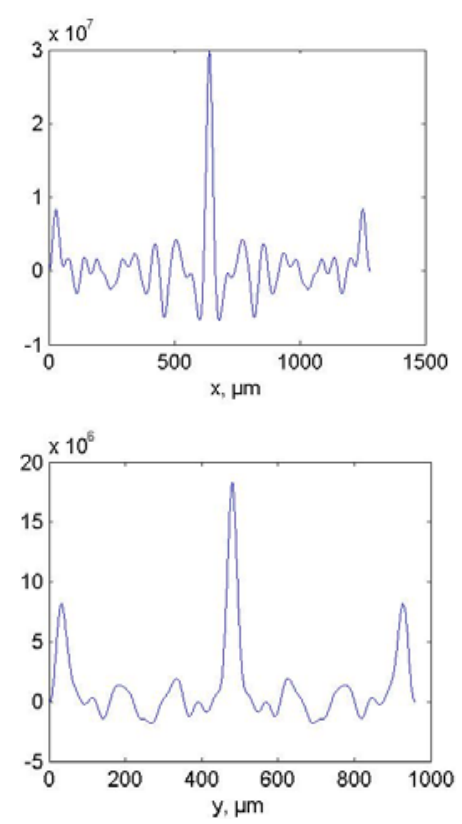

Рис. 3. Автокореляційні функції $K_{a}(\Delta x)$ розподілів величини вейвлет- коефіцієнтів поляризаційної мапи еліптичності поляризації цифрового мікроскопічного зображення міокарда: а) - зображення міокарда контрольної групи; б) - групи померлих від ГКН 
Таблиця 1

Статистичні моменти 1-4-го порядків автокореляційних функцій $K_{a}(\Delta x)$ розподілу вейвлет коефіціснтів поляризаційних мап еліптичності лазерних цифрових мікроскопічних зображень зрізів міокарда за умов хронічної ішемічної хвороби серця та гострої коронарної недостатності

\begin{tabular}{|c|c|c|c|c|c|}
\hline \multicolumn{3}{|c|}{ XIXC (27 зразків) } & \multicolumn{3}{|c|}{ ГКН (30 зразків) } \\
\hline$a_{\min }$ & \multicolumn{2}{|c|}{$M_{j}$} & $a_{\min }$ & \multicolumn{2}{|c|}{$M_{j}$} \\
\hline \multirow{4}{*}{$a_{\min }=2 \mu m$} & $\mathrm{M}_{1}$ & $0,75 \pm 0,086$ & $a_{\min }=2 \mu m$ & $\mathrm{M}_{1}$ & $0,69 \pm 0,084$ \\
\hline & $\mathrm{M}_{2}$ & $0,12 \pm 0,018$ & & $\mathrm{M}_{2}$ & $0,25 \pm 0,033$ \\
\hline & $\mathrm{M}_{3}$ & $0,29 \pm 0,038$ & & $\mathrm{M}_{3}$ & $0,74 \pm 0,087$ \\
\hline & $\mathrm{M}_{4}$ & $0,47 \pm 0,062$ & & $\mathrm{M}_{4}$ & $1,02 \pm 0,13$ \\
\hline \multirow{5}{*}{$a_{\min }=10 \mu m$} & \multicolumn{2}{|c|}{$M_{j}$} & $a_{\min }=10 \mu m$ & \multicolumn{2}{|c|}{$M_{j}$} \\
\hline & $\mathrm{M}_{1}$ & $0,64 \pm 0,071$ & & $\mathrm{M}_{1}$ & $0,54 \pm 0,067$ \\
\hline & $\mathrm{M}_{2}$ & $0,17 \pm 0,024$ & & $\mathrm{M}_{2}$ & $0,27 \pm 0,036$ \\
\hline & $\mathrm{M}_{3}$ & $0,73 \pm 0,085$ & & $\mathrm{M}_{3}$ & $2,39 \pm 0,36$ \\
\hline & $\mathrm{M}_{4}$ & $0,83 \pm 0,091$ & & $\mathrm{M}_{4}$ & $2,18 \pm 0,36$ \\
\hline \multirow{5}{*}{$a_{\min }=30 \mu m$} & \multicolumn{2}{|c|}{$M_{j}$} & $a_{\min }=30 \mu \mathrm{m}$ & \multicolumn{2}{|c|}{$M_{j}$} \\
\hline & $\mathrm{M}_{1}$ & $0,57 \pm 0,069$ & & $\mathrm{M}_{1}$ & $0,49 \pm 0,058$ \\
\hline & $\mathrm{M}_{2}$ & $0,23 \pm 0,031$ & & $\mathrm{M}_{2}$ & $0,34 \pm 0,038$ \\
\hline & $\mathrm{M}_{3}$ & $0,92 \pm 0,14$ & & $\mathrm{M}_{3}$ & $4,83 \pm 0,56$ \\
\hline & $\mathrm{M}_{4}$ & $1,12 \pm 0,17$ & & $\mathrm{M}_{4}$ & $3,84 \pm 0,43$ \\
\hline
\end{tabular}

Розподіл зразків за вейвлет-аналізом кореляційної структури розподілів еліптичності

Таблиця 2 поляризації лазерних цифрових мікроскопічних зображень зразків гістологічних зрізів міокарда групи 1 (ХIXC) і групи 2 (ГКН)

\begin{tabular}{|c|c|c|c|}
\hline \multirow{2}{*}{ Вейвлет-аналіз } & \multicolumn{2}{|c|}{ Патологія (ГКН) } & \multirow{2}{*}{ Всього } \\
\hline & (XIXC, група 1) & (ГКН, група 2) & \\
\hline \multicolumn{4}{|c|}{ Статистичний момент 2-го порядку $\mathrm{M}_{2}$ (масштаб $\left.a_{\min }=2 \mu m\right)$} \\
\hline Позитивні & 10 & 21 & 31 \\
\hline Негативні & 17 & 9 & 26 \\
\hline Всього & 27 & 30 & 57 \\
\hline \multicolumn{4}{|c|}{ Статистичні моменти 3-го $\mathrm{M}_{3}$ i 4-го $\mathrm{M}_{4}$ порядку (масштаб $a_{\min }=2 \mu m$ ) } \\
\hline Позитивні & 8 & 23 & 31 \\
\hline Негативні & 19 & 7 & 26 \\
\hline Всього & 27 & 30 & 57 \\
\hline \multicolumn{4}{|c|}{ Статистичний момент 2-го порядку $\mathrm{M}_{2}$ (масштаби $\left.a_{m i n}=10 \mu m ; 30 \mu m\right)$} \\
\hline Позитивні & 9 & 20 & 29 \\
\hline Негативні & 18 & 10 & 28 \\
\hline Всього & 27 & 30 & 57 \\
\hline \multicolumn{4}{|c|}{ Статистичні моменти 3-го $\mathrm{M}_{3}$ i 4-го $\mathrm{M}_{4}$ порядку (масштаби $\left.a_{\min }=10 \mu m ; 30 \mu \mathrm{m}\right)$} \\
\hline Позитивні & 7 & 25 & 32 \\
\hline Негативні & 20 & 5 & 25 \\
\hline Всього & 27 & 30 & 57 \\
\hline
\end{tabular}

сукупность вейвлет-коефіцієнтів для кожного k-го рядка пікселів світлочутливої площадки цифрової камери 10 (рис. 1, рис. 2).
Дослідження автокореляційних функцій $K_{a}(\Delta x)$ на трьох структурних розмірах поляризаційних мап лазерних цифрових мікроскопічних 
Таблиця 3

Операційні характеристики інформативності вейвлет-аналізу кореляційної структури розподілів еліптичності поляризації лазерних цифрових мікроскопічних зображень зразків гістологічних зрізів міокарда групи 1 (XIXC) і групи 2 (ГКН)

\begin{tabular}{|c|c|c|c|c|}
\hline Параметри & $\begin{array}{c}\mathrm{M}_{2} \\
a_{\min }=2 \mu m\end{array}$ & $\begin{array}{c}\mathrm{M}_{3}, \mathrm{M}_{4} \\
a_{\min }=2 \mu m\end{array}$ & $\begin{array}{c}\mathrm{M}_{2} \\
a_{\min }=10 \mu m ; 30 \mu m\end{array}$ & $\begin{array}{c}\mathrm{M}_{3}, \mathrm{M}_{4} \\
a_{\min }=10 \mu m ; 30 \mu m\end{array}$ \\
\hline Чутливість $S e, \%$ & 70 & 77 & 67 & 83 \\
\hline Специфічність $S p, \%$ & 63 & 70 & 63 & 78 \\
\hline Точність $A c, \%$ & 67 & 74 & 69 & 78 \\
\hline $\begin{array}{c}\text { Прогностичність пози- } \\
\text { тивного результату +VP, } \\
\text { \% }\end{array}$ & 68 & 74 & 64 & 80 \\
\hline $\begin{array}{c}\text { Прогностичність нега- } \\
\text { тивного результату } \\
\text {-УР, \% }\end{array}$ & 65 & 73 & 65 & 78 \\
\hline
\end{tabular}

зображень шарів міокарда при XIXC (рис. 3a) та шарів міокарда за умов ГКН (рис. 3б) показало, що автокореляційні функції $K_{a}(\Delta x)$ розподілів вейвлет - коефіцієнтів мап еліптичності поляризації лазерних зображень обох груп індивідуальні для кожного масштабу.

Порівняльний аналіз статистичної структури автокореляційних функцій розподілів вейвлеткоефіцієнтів поляризаційних мап еліптичності лазерних цифрових мікроскопічних зображень гістологічних зрізів тканини міокарда обох груп виявив (табл. 1):

1) Суттєві відмінності (у межах 2,2 раза) величини дисперсії автокореляційної функції $K_{a}(\Delta x)$ на масштабі $\alpha_{\min }=2 \mu \mathrm{m}$ МНАТ - вейвлету.

2) Значне збільшення розбіжностей величин статистичних моментів 3-го (у 2,5-4,4 раза) і 4-го (у 2,1-3,2 раза) порядків автокореляційних функцій, $K_{a}(\Delta x)$ визначених для більших масштабів $\alpha_{\min }=10 \mu \mathrm{m} ; 30 \mu \mathrm{m}$ МНАТ - вейвлету.

Виявлені відмінності статистичних моментів $M_{j=1 ; 2 ; 3 ; 4}$ які характеризують автокореляційні функції $K_{a}(\Delta x)$, можна пов'язати 3 тим, що ГКН найбільш виразно виявляється у змінах оптикофізичних властивостей тканини міокарда на малих масштабах міозинових структур. Такий процес призводить до зростання показника двопроменезаломлення парціальних кристалів міозину розупорядкованих за напрямами оптичних осей.

Поляризаційно такі процеси виявляються у формуванні складних асиметричних розподілів еліптичності поляризації відповідних лазерних цифрових мікроскопічних зображень шару міокарда у випадку гострої коронарної недостатності.

Результати застосування даного методу вейвлет-аналізу кореляційної структури розподілів еліптичності поляризації лазерних цифрових мікроскопічних зображень зразків гістологічних зрізів міокарда групи 1 (ГКН) і групи 2 (IXC) для кожного об'єктивного параметра $\mathrm{M}_{\mathrm{j}=1 ; 2 ; 3 ; 4}$ зведено в матрицю рішень, яку ілюструє таблиця 2 .

Визначені на основі матриці рішень (табл. 2) операційні характеристики вейвлет-аналізу кореляційної структури розподілів еліптичності поля- ризації лазерних цифрових мікроскопічних зображень зразків гістологічних зрізів міокарда групи 1 (ХІХC) і групи 2 (ГКН), наведені в таблиці 3.

Аналіз одержаних даних виявив наступне:

- установлено, що для статистичного моменту $M_{2}\left(a_{\min }=2 \mu m\right)$ кількість позитивних і хибно негативних рішень складає 21 та 9 (чутливість $\mathrm{Se}=70 \%$ ), а кількість негативних і хибно позитивних рішень складає 17 та 10 (специфічність $S p=63 \%$ );

- установлено, що для статистичних моментів 3-го $M_{3}$ і 4-го $M_{4}$ порядку (масштаб $a_{\min }=2 \mu \mathrm{m}$ ) кількість позитивних і хибно негативних рішень складає 23 та 7 (чутливість $S e=77 \%$ ), а кількість негативних і хибно позитивних рішень складає 19 та 8 (специфічність $S p=70 \%$ );

- установлено, що для статистичного моменту $M_{2}\left(a_{\min }=10 \mu m ; 30 \mu m\right)$ кількість позитивних $\mathrm{i}$ хибно негативних рішень складає 20 та 10 (чутливість $S e=67 \%$ ), а кількість негативних і хибно позитивних рішень складає 18 та 9 (специфічність $S p=63 \%$ );

- установлено, що для статистичних моментів 3-го $M_{3}$ і 4-го $M_{4}$ порядку $\left(a_{\min }=10 \mu \mathrm{m} ; 30 \mu \mathrm{m}\right)$ кількість позитивних і хибно негативних рішень складає 25 та 5 (чутливість $S e=83 \%$ ), а кількість негативних і хибно позитивних рішень складає 20 та 7 (специфічність $S p=74 \%$ );

- точність методу $A c$ становить 65\%-78\% 3 наступними параметрами прогностичності $+\mathrm{VP}=68 \%-78 \% \mathrm{i}+\mathrm{VP}=64 \%-80 \%$.

\section{Висновок}

Запропоновано новий об'єктивний метод вейвлет-аналізу кореляційної структури мап еліптичності поляризації цифрових поляризаційних мікроскопічних зображень гістологічних зрізів міокарда для діагностики гострої коронарної недостатності зокрема та проведення диференційної діагностики із суміжною патологією - хронічною ішемічною хворобою серця.

Перспектива подальших досліджень. Подальші дослідження структури міокарда за умов 
гострої коронарної недостатності за допомогою лазерної поляриметрії дадуть можливість створити базу характеристик іiі зображень, як теоретичну основу для практичної діагностики даного виду патології.

Автор висловлює щиру подяку доктору фізико-математичних наук, завідувачу кафедри оптики і спектроскопії, проректору з наукової роботи Чернівецького національного університету імені Юрія Федьковича, професору Ушенку Олександру Григоровичу та колективу його лабораторії за детальне обговорення результатів роботи та стимулювальні дискусії.

\section{Література}

1. Angelsky O.V. Polarization reconstruction of orientation structure of biological tissues birefringent architectonic nets by using their Mueller-matrix speckle-images / O.V. Angelsky, A.G. Ushenko, Yu.A. Ushenko // J. Holography Speckle 2. -2005 . - P. 72-79.

2. Birefringence characterization of biological tissue by use of optical coherence tomography / M. J. Everett, K. Shoenenberger, B. W. Colston [et al.] // Opt. Lett. 1998. - Vol. 23. - P. 228-230.

3. Investigation of 2D Mueller matrix structure of biological tissues for pre-clinical diagnostics of their pathological states / O. Angelsky, Yu. Tomka, A. Ushenko [et al.] // J Phys. D: Appl. Phys. - 2005. - Vol. 38. - P. 4227-4235.

\section{ПРИНЦИПЫ ДОКАЗАТЕЛЬНОЙ МЕДИЦИНЫ ДЛЯ ЛОКАЛЬНОГО МАСШТАБНО- СЕЛЕКТИВНОГО КОРРЕЛЯЦИОННОГО АНАЛИЗА РАСПРЕДЕЛЕНИЙ \\ ЭЛЛИПТИЧНОСТИ ПОЛЯРИЗАЦИИ ЛАЗЕРНЫХ ЦИФРОВЫХ МИКРОСКОПИЧЕСКИХ ИЗОБРАЖЕНИЙ МИОКАРДА ПРИ УСЛОВИИ ОСТРОЙ ИШЕМИИ}

\section{О.Я. Ванчуляк}

Резюме. В работе освещены показатели, объективно свидетельствующие о повреждении миокарда человека при острой ишемии. На основе принципов доказательной медицины обоснована целесообразность использования вейвлет-анализа корреляционной структуры карт эллиптичности поляризации лазерных изображений миокарда для диагностики острой коронарной недостаточности и определены операционные характеристики силы данного метода.

Ключевые слова: поляризационная микроскопия, острая коронарная недостаточность, судебно-медицинская экспертиза.

\section{THE PRINCIPLES OF EVIDENTIAL MEDICINE FOR A LOCAL LARGE-SCALE-SELECTIVE CORRELATION ANALYSIS OF THE DISTRIBUTIONS OF ELLIPTICITY FOR THE POLARIZATION OF LASER DIGITAL MICROSCOPIC IMAGES OF THE MYOCARDIUM UNDER THE CONDITIONS OF ACUTE ISCHEMIA}

\section{O.Ya. Wanchuliak}

Abstract. This paper ascertains the use of indicators that objectively show evidence of damage to the human myocardium under conditions of acute ischemia. On the basis of the principles of evidence-based medicine, the feasibility, effectiveness, and operational characteristics of the application of wavelet analysis of the correlation structure of maps of ellipticity in polarization laser images for the diagnosis of acute coronary insufficiency are shown

Key words: polarization microscopy, acute coronary insufficiency, forensic-medical examination.

Bukovinian State Medical University (Chernivtsi) 